\title{
Characteristics Of Minerals With Spectroscopic IR At The Gold Mining Area Of Botak Mountain
}

\author{
Helda Andayany* and Josephus Ronny Kelibulin
}

\begin{abstract}
There are three rock samples that have been taken from the gold mining area of Botak mountain. The rock samples were then analyzed with spectroscopic IR to estimate the characteristic of mineral in the area. Analysis results indicate that the type of mineral found in rock samples 2 is dominated by Kaolinite, Organic Carbon, Palygorskite and Quartz. So it can be estimate the type of rock contained in that area is Quartzite. The analysis result of mineral type analysis on rock samples 1 dan 3 have similarities that is Kaolinite, Organic Carbon, Palygorskite, and Albite. So it can be estimate that the other types of rock in the area are Andesite and Limestone. The existence of Andesit and Limestone shows that there has been alteration and hydrothermal mineralization from volcanic origin rock. So it can be estimate that these rocks are the bearing rocks and hosted rocks of base metals and gold. Whereas the quartzite is a bond mineral from gold carrying rocks.
\end{abstract}

Keywords: spectroscopic IR; gold; Andesit; Quartzite; Limestone.

\section{INTRODUCTION}

Geological history explains that Buru Islands is included in the South Moluccas region which is the Banda Arc, the archipelagic system that forms an arc around the horseshoe basin of the Banda Sea that opens to the West. South Moluccas is bounded by deep bows (active volcanism) and external bows (free from volcanism)[1]. Buru Island is included in the outer Arc that has a dominated by structural mountains. Geological history also explains that the island of Buru is part of the Maluku Islands is composed of shallow sea deposits estimated to be aged Plitosen until Holocene. The composition of rocks consist of limestone, napal, and alluvium deposits. Formation of rock compilers of Buru Island region starts from the youngest of which is Formation of Tassel, Hemorrhoid Formation and Alluvium Formation. So there are variations of rocks on Buru Island, which are alluvium, limestone, corals, napal, sandstone, conglomerate, andesite and basalt tuffs. There are also filit, skist and quartzite[2].

The Botak Mountain area is located in Namlea, Buru Island. This area is a gold mining area of the people. The historical background of this region's geology

\footnotetext{
${ }^{*}$ Correspondence: heldaandayany2014@gmail.com

Department Of Physics, Faculty of Mathematics and Natural Sciences,

Pattimura University, 97233, Ambon, Indonesia

Full list of author information is available at the end of the article

${ }^{\dagger}$ Equal contributor
}

strongly proves the presence of gold veins in the area. The mineral characteristics in the gold mining area are both gold-carrying minerals which are usually associated with bonded minerals and sulphide deposits that have been oxidized in the gold mining area of Botak Mountain.

The gold mining area of Botak Mountain is dominated by 3 (three) types of rocks that are interpreted related to gold mineralization. These rocks are andesite, quartzite and limestone which is undergoing alteration and is a member of the Alluvium Formation. The rocks that are most affected and serve as trap rock for the occurrence of mineralization are limestone and quartzite. For rocks that are interpreted as gold metal carriers are basaltic andesite veins.

Based on the above, this research is intended to interpret the types of minerals and rocks that experience alteration and mineralization of volcanic rocks. In addition, it can interpretation the rock that serves as a trap (hosted rocks) and gold bearer rock (gold bearing rocks). This is done by analyzing rock samples taken from the gold mining area of Botak Mountain using spectroscopic IR.

\section{PREVIOUS STUDY}

The geological structure and tectonic history of the Bald Mountain area, Buru Island is very influential on the gold formation process in this area. Stratigraphy of Buru Island[3], consisting of metamorphic rocks (filit, 
Table 1. Transmittance Spectrum Area On Rock Samples 1

\begin{tabular}{|c|c|c|c|c|c|c|c|}
\hline Sample & Compounds & $\begin{array}{c}\text { Function } \\
\text { groups }\end{array}$ & $\begin{array}{c}\text { Wavenumber } \\
\left(\mathrm{cm}^{-1}\right)\end{array}$ & $\begin{array}{c}\text { Analysis result of } \\
\text { spectroscopy IR } \\
\left(\mathrm{cm}^{-1}\right)\end{array}$ & $\begin{array}{c}\text { Transmittance } \\
(\%)\end{array}$ & Intensity & $\begin{array}{c}\text { Types of } \\
\text { minerals }\end{array}$ \\
\hline \multirow{2}{*}{$\begin{array}{c}\text { Rock } \\
1\end{array}$} & Amine & $\mathrm{N}-\mathrm{H}$ & $3300-3500$ & 3441 & 8.94 & Medium & Kaolonite \\
\cline { 2 - 8 } & Alkine & $\mathrm{C}-\mathrm{H}$ & $2850-3000$ & 2916 & 14.02 & Strong & $\begin{array}{c}\text { Organic } \\
\text { Carbon }\end{array}$ \\
\cline { 2 - 8 } & Alkene & $\mathrm{C}=\mathrm{C}$ & $1620-1680$ & 1628 & 8.99 & Variable & Palygorskite \\
\cline { 2 - 8 } & Ether & $\mathrm{C}-\mathrm{O}$ & $1000-1300$ & 1018 & 0.08 & Strong & Albite \\
\hline
\end{tabular}

skist and quartzite), sedimentary rock (limestone) and volcanic rock (tufa andesite and basalt). Gold is a soft and malleable metal, its hardness ranges from 2.5 to 3 (Mohs scale), as well as its specific gravity depending on the type and content of other metals combined with it. Gold carriers are usually associated with minerals. Such minerals are generally quartz, carbonate, tourmaline, flourspar, and small amounts of nonmetallic minerals. Gold-carrying minerals are also associated with rock-forming minerals such as oxidized sulphide deposits. If sulfide minerals are absent in rocks, gold is associated with iron oxide (magnetite and secondary iron oxide), silica and carbonate, carbon and sand and gravel (plasmal deposits)[4].

The formation of gold in nature through a process of magmatism from the earth's core or the concentration of minerals to the surface, as well as the activity of the volcanic from the volcano. The gap from the volcanic activity causes high-pressure magmatic water to rise to the surface of the earth. When magmatic water in the form of steam reaches the surface of the earth comes in contact with meteoric water which causes sulphide ions and chloride ions that carry the precipitated gold. Meteoric water usually occupies the zones of frozen rock cracks that undergo alteration processes due to warming by magmatic water. As the mineral deposits increase on the cracks, the longer the cracks are closed by the accumulation of deposits from metals containing complex ions containing gold, while the mechanical concentration activity produces a placer deposit. Gold deposits are categorized into two: primary deposits which are deposits of igneous rock and gold minerals forming gold or gold veins (vein) and deposits of plates originating from golden rock deposits that have been eroded by water into streams (usually deposits The placer is present in the waterway below the hill or mountains)[5].

Gold deposits can also be formed through the process of weathering frozen rock and gold veins that can erode and remove gold minerals where gold minerals will be sedimented in very fine-grained materials, clay minerals (kaolinite) [6]. But if there is no intrusion, gold minerals could have existed in limestone.

\section{METHODS}

The sample used in this study amounted to three samples, namely 3 rock samples from the gold mining area at Botak Mountain, Buru District and then analyzed by using IR spectroscopy 3000[7]. From the result of the sample test to threes rocks, we get the graph of transmittance spectrum (\%) vs. wave number $\left(\mathrm{cm}^{-1}\right)$, then the graph to interpreted functional group, compound, vibration type, intensity and mineral type contain in each rock sample.

Rock samples taken from the gold mining area of Botak Mountain, smoothed and then added pure $\mathrm{KBr}$ powder and stirred until evenly distributed. Next, the mixture is placed in the mold and pressed by means of a mechanical pressure device then the sample $(\mathrm{KBr}$ pellet formed) is taken and analyzed. The analysis results show that the value of the wavelengths analyzed from the absorbance and transmitance spectrum generated from the IR spectroscopic[3]. The value of wave number will be used to interpret the mineral and rock types found in the gold mining area of Gunung Botak.

\section{RESULTS AND DISCUSSION}

The result of analysis of rock samples with spectroscopic IR is shown by IR spectrum graph in Figures 1, 2, and 3. In Fig. 1, in the area with wave numbers $3300-3500$ there is a stretching function group that is an amine compound. In addition, in the area with wave numbers $2850-3000$ there is a stretching $C-H$, there is also a function group $C=C$ with the geometrical area of $1620-1680 \mathrm{~cm}^{-1}$ and the function group $C=O$ with wave number $1679-$ $1820 \mathrm{~cm}^{-1}$. Graph 1 indicates that there are several wave numbers that are not included in absorption function, there are only a few wave numbers included in the absorbant function group.

The result of spectrum graph analysis of IR spectroscopic of rock samples 1 shows that the function group $N-H$ from wave number $(3300-3500)$ $\mathrm{cm}^{-1}$ with IR spectroscopic analysis $3441 \mathrm{~cm}^{-1}$ and absorbance $8.94 \%$ have amine compound, function group $C-H$ from wave number $(2850-3000) \mathrm{cm}^{-1}$ with spectroscopic analysis of $I R 2916 \mathrm{~cm}^{-1}$ and 
Table 2. Transmittance Spectrum Area On Rock Samples 2

\begin{tabular}{|c|c|c|c|c|c|c|c|}
\hline Sample & Compounds & $\begin{array}{c}\text { Function } \\
\text { groups }\end{array}$ & $\begin{array}{c}\text { Wavenumber } \\
\left(\mathrm{cm}^{-1}\right)\end{array}$ & $\begin{array}{c}\text { Analysis result of } \\
\text { spectroscopy IR } \\
\left(\mathrm{cm}^{-1}\right)\end{array}$ & $\begin{array}{c}\text { Transmittance } \\
(\%)\end{array}$ & Intensity & $\begin{array}{c}\text { Types of } \\
\text { minerals }\end{array}$ \\
\hline \multirow{2}{*}{$\begin{array}{c}\text { Rock } \\
2\end{array}$} & Amine & $\mathrm{N}-\mathrm{H}$ & $3300-3500$ & 3441 & 0.72 & Medium & Kaolonite \\
\cline { 2 - 8 } & Alkine & $\mathrm{C}-\mathrm{H}$ & $2850-3000$ & 2924 & 0.72 & Strong & $\begin{array}{c}\text { Organic } \\
\text { Carbon }\end{array}$ \\
\cline { 2 - 8 } & Alkene & $\mathrm{C}=\mathrm{C}$ & $1620-1680$ & 1628 & 0.95 & Variable & Palygorskite \\
\cline { 2 - 8 } & Ether & $\mathrm{C}-\mathrm{O}$ & $1000-1300$ & 1018 & 2.22 & Strong & Kuarsa \\
\hline
\end{tabular}

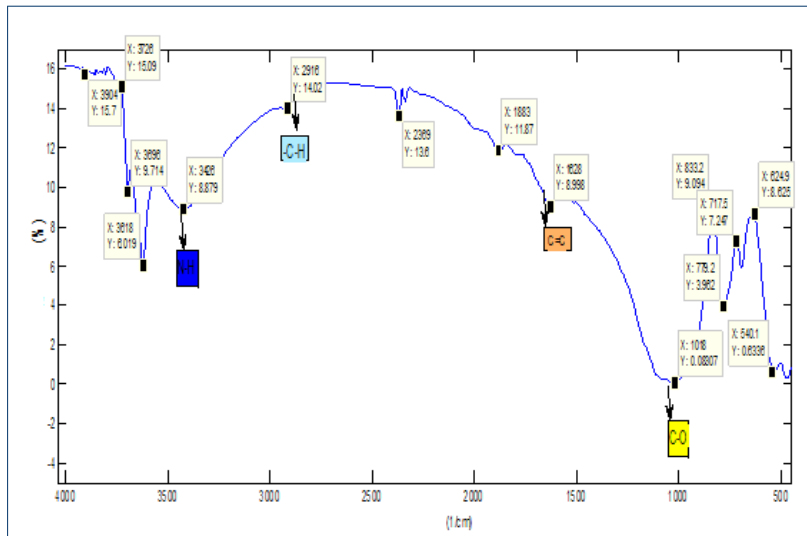

Figure 1. Spectrum IR from Rock Samples 1

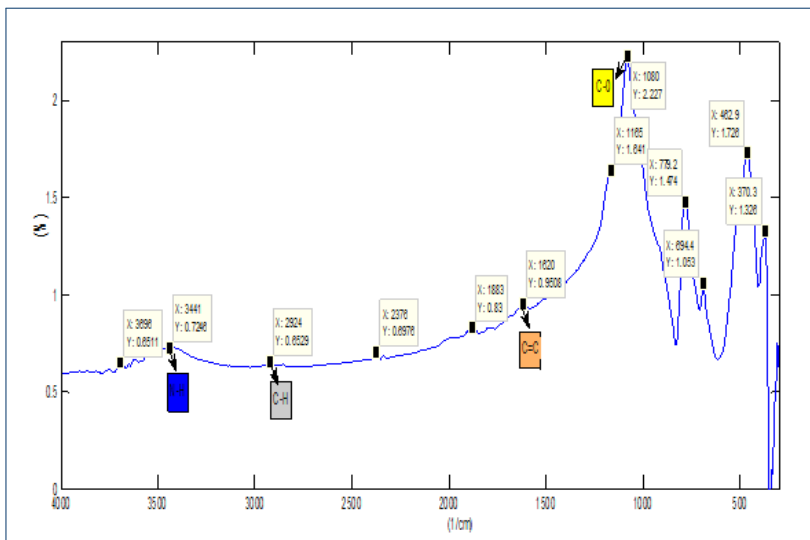

Figure 2. Spectrum IR from Rock Samples 2 absorbance $14.02 \%$ had alkane compound, function group $C=C$ from wave number $(1620-1680)$ $\mathrm{cm}^{-1}$ with spectroscopic IR analysis $1628 \mathrm{~cm}^{-1}$ and an absorbance value of $8.99 \%$ having alkene compound, and function group $C-O$ from a wave number $(1000-1300) \mathrm{cm}^{-1}$ with spectroscopic IR analysis of $1018 \mathrm{~cm}^{-1}$ and an absorption value of $0.08 \%$ having ether compounds. Thus the mineral types of each group are kaolinite, organic carbon, palygorskite and albite (table 1).

In FIG. 2, the spectrum graph is identified as a function group in different regions of the wave number. In the wavelength $(3300-3500) \mathrm{cm}^{-1}$ region there is a stretching function group $N-H$ that is an amine compound. Furthermore, the area of the wave number (2850-3000) $\mathrm{cm}^{-1}$ is stretching function group $C-H$, there is also a function group $C=C$ with the geometrical region $(1620-1680) \mathrm{cm}^{-1}$ and the function group $C-O$ with the wave number $(1679-1820)$ $\mathrm{cm}^{-1}$. Graph 2 also shows that there are several wave numbers that are not included in the characteristics of the IR spectroscopic absorption function, there are only a few wave numbers included in the absorbant function group.

The result of IR spectrum graphic analysis for rock samples 2 shows that the function group $\mathrm{N}-\mathrm{H}$ from wave number $(3300-3500) \mathrm{cm}^{-1}$ with IR spectroscopic analysis $3441 \mathrm{~cm}^{-1}$ and $0.72 \%$ absorption have amine compound, function group $C-H$ with wave number $(2850-3000) \mathrm{cm}^{-1}$ with spectroscopic IR analysis $2924 \mathrm{~cm}^{-1}$ and $0.65 \%$ uptake, having alkane compound, function group $C=C$ from wave number $(1620-1680) \mathrm{cm}^{-1}$ with spectroscopic IR analysis $1620 \mathrm{~cm}^{-1}$ and $0.95 \%$ absorption value having alkene compound, and the function group $C-O$ from wave number $(1000-13000) \mathrm{cm}^{-1}$ with spectroscopic IR analysis of $1080 \mathrm{~cm}^{-1}$ and an absorption value of $2.22 \%$ having an ether compound. Thus the mineral types of each group are kaolinite, organic carbon, palygorskite and quartz (table 2).

In FIG. 3, the spectrum graph is identified as a function group in different regions of the wave number. In the wavelength $(3300-3500) \mathrm{cm}^{-1}$ region there is a stretching function group $N-H$ that is an amine compound. Next, there is a $C-H$ stretching function group, there is also a function group $C=C$ with a wave number region $(1620-1680) \mathrm{cm}^{-1}$ and a function group $C-O$ with the wave number $(1679-1820)$ $\mathrm{cm}^{-1}$. From the graph above also shows that there are several wave numbers that are not included in the characteristic of the IR spectroscopic absorption function, there are only a few wave numbers included in the cluster of absorbent function group.

The result of IR spectrum graphic analysis for rock samples 3 shows that the function group $\mathrm{N}-\mathrm{H}$ from wave number $(3300-3500) \mathrm{cm}^{-1}$ with spectroscopic 
Table 3. Transmittance Spectrum Area On Rock Samples 3

\begin{tabular}{|c|c|c|c|c|c|c|c|}
\hline Sample & Compounds & $\begin{array}{c}\text { Function } \\
\text { groups }\end{array}$ & $\begin{array}{c}\text { Wavenumber } \\
\left(\mathrm{cm}^{-1}\right)\end{array}$ & $\begin{array}{c}\text { Analysis result of } \\
\text { spectroscopy IR } \\
\left(\mathrm{cm}^{-1}\right)\end{array}$ & $\begin{array}{c}\text { Transmittance } \\
(\%)\end{array}$ & Intensity & $\begin{array}{c}\text { Types of } \\
\text { minerals }\end{array}$ \\
\hline \multirow{2}{*}{$\begin{array}{c}\text { Rock } \\
3\end{array}$} & Amine & $\mathrm{N}-\mathrm{H}$ & $3300-3500$ & 3395 & 0.83 & Medium & Kaolonite \\
\cline { 2 - 8 } & Alkine & $\mathrm{C}-\mathrm{H}$ & $2850-3000$ & 2855 & 0.61 & Strong & $\begin{array}{c}\text { Organic } \\
\text { Carbon }\end{array}$ \\
\cline { 2 - 8 } & Alkene & $\mathrm{C}=\mathrm{C}$ & $1620-1680$ & 1628 & 0.68 & Variable & Palygorskite \\
\cline { 2 - 8 } & Ether & $\mathrm{C}-\mathrm{O}$ & $1000-1300$ & 1088 & 1.30 & Strong & Albite \\
\hline
\end{tabular}

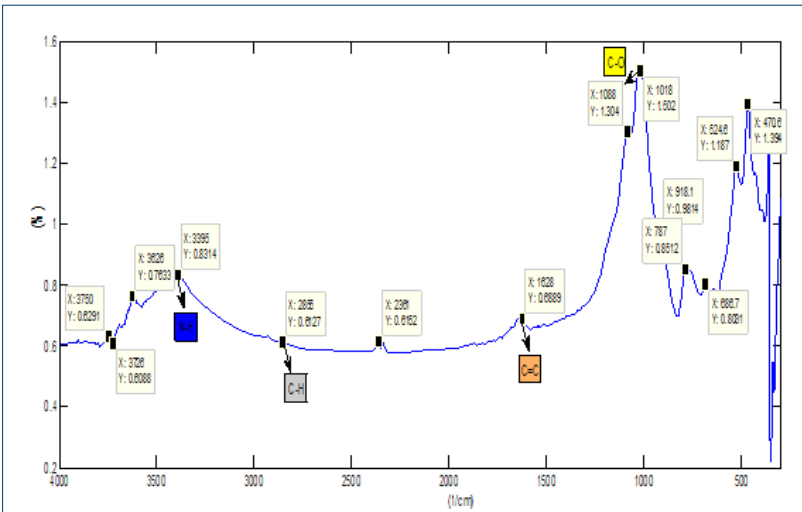

Figure 3. Spectrum IR from Rock Samples 3

IR analysis of $3395 \mathrm{~cm}^{-1}$ and $0.83 \%$ absorption have amine compound, function group $\mathrm{C}-\mathrm{H}$ from wave number $(2850-3000) \mathrm{cm}^{-1}$ with spectroscopic analysis IR $2855 \mathrm{~cm}^{-1}$ and its absorption $0.61 \%$ has alkane compound, function group $C=C$ from wave number $(1620-1680) \mathrm{cm}^{-1}$ with analysis of IR spectroscopic $1628 \mathrm{~cm}^{-1}$ and absorption value $0.68 \%$ has alkene compound, and function group $C-O$ from wave number $(1000-13000) \mathrm{cm}^{-1}$ with IR spectroscopic analysis of $1088 \mathrm{~cm}^{-1}$ and an absorption value of $1.30 \%$ have ether compound. Thus the mineral types of each group are kaolinite, organic carbon, palygorskite and albite (table 3).

The results of spectroscopic IR analysis on rock samples in the gold mining area of Botak Mountain, Buru Island showed rock samples 1, 2 and 3 were dominated by function group of $N-H, C-H, C=$ $C$ and $C-O$. In rock samples 1 with the $C-H$ function group which is the alkane compound has the highest transmittance of $14.02 \%$ and the wave number $2916 \mathrm{~cm}^{-1}$. While for rock samples 2 and 3 have the highest absorbance value of $2.22 \%$ for the function group $C-O$ ether compound, with the wave number $1080 \mathrm{~cm}^{-1}$.

Based on the type of minerals obtained from the IR spectroscopic analysis, it can be interpreted by the type of rocks based on the minerals that have been analyzed. The interpreted rock types are presented in
Table 4. The analysis result of mineral type on rock samples 1 and 3 have similarities that is dominated by Kaolinite, Organic Carbon, Palygorskite and albite. These minerals have undergone alteration and are associated with gold-carrying minerals. These minerals are much found on Andesite rocks. So it can be estimate that the type of rock in the area is Andesite. The analysis result of mineral type on rock samples 2 is Kaolinite, Organic Carbon, Palygorskite, and Quartz. These minerals are much found on limestone and quartzite rocks. So it can be estimate that the type of rock in the area is Limestone and Quartzite.

Thus the results of this study can show that in accordance with the geological structure and tectonic history, that Buru Island consisting of metamorphic rock (filit, skist and quartzite), sedimentary rocks (rocks) and volcanic rock (tufa andesite and basalt). The types of rocks found in the area of Botak Mountain, Buru Island is very influential on the process of forming gold in this area. The Andesite, quartzite and limestone that are teralterasi are members of the Alluvium Formation. The rocks that are most affected and serve as rock traps (traps) for the occurrence of mineralization are limestone and quartzite. For rocks that are interpreted as gold metal carriers are basaltic andesite veins.

\section{CONCLUSIONS}

The analysis results of mineral type on rock samples 1 and 3 have similarities that are dominated by Kaolinite, Organic Carbon, Palygorskite and albite. These minerals undergone changes and are associated with gold-carrying minerals. This mineral much found in the Andesite rocks. So it can be estimated that types of rocks in the area are Andesite. The analysis results of mineral type on rock samples 2 were Kaolinite, Organic Carbon, Palygorskite, and Quartz. This mineral much found in the Limestone and quartzite rocks.

The existence of the Andesite shows that there has been a change and hydrothermal mineralization on volcanic origin rocks. So it can be estimate that these rocks are the bearing rocks and hosted rocks of base metals and gold. Whereas the limestone and quartzite is a bond mineral from gold carrying rock. 
Table 4. Interpretation of rock type based on minerals forming rocks.

\begin{tabular}{|c|c|c|c|c|c|}
\hline $\begin{array}{c}\text { Samples } \\
\text { to }\end{array}$ & Types of minerals & $\begin{array}{c}\text { Types of } \\
\text { rocks }\end{array}$ & Color & Form & Rock group \\
\hline 1 & $\begin{array}{c}\text { Kaolinite, organic } \\
\text { carbon, palygorskite } \\
\text { and albite }\end{array}$ & Andesite & Browning & Square & $\begin{array}{c}\text { Igneous } \\
\text { rocks }\end{array}$ \\
\hline 2 & $\begin{array}{c}\text { Kaolinite, organic } \\
\text { carbon, palygorskite } \\
\text { and quartz }\end{array}$ & Quartzite & $\begin{array}{c}\text { Crystal } \\
\text { white }\end{array}$ & Square & $\begin{array}{c}\text { Metamorphic } \\
\text { rocks }\end{array}$ \\
\hline 3 & $\begin{array}{c}\text { Kaolinite, organic } \\
\text { carbon, palygorskite } \\
\text { and albite }\end{array}$ & Limestone & $\begin{array}{c}\text { Grayish } \\
\text { white }\end{array}$ & Square & $\begin{array}{c}\text { Sedimentary } \\
\text { rocks }\end{array}$ \\
\hline
\end{tabular}

\section{ACKNOWLEDGMENTS}

A big thank you addressed to the Dean of the faculty of Mathematics and Natural Sciences university of Pattimura which helps research equipment facilities.

\section{AUTHOR}

1 Helda Andayany

Dari :

(1) Department Of Physics, Faculty of Mathematics and Natural Sciences, Pattimura University

2 Josephus Ronny Kelibulin

Dari :

(1) Department Of Physics, Faculty of Mathematics and Natural Sciences, Pattimura University

Pustaka

1. Darman H. An Outline Of The Geology Of Indonesia. Jakarta: Ikatan Ahli Geologi Indonesia; 2009.

2. Bemmelan RWv. The Geology Of Indonesia, Physiography. Amsterdam: The Hague Publishing Co; 1970.

3. Silverstein RM, Bassler GC, Moril TC. Spectrometric Identification of Organic Compounds. 4th ed. USA: Jhon Willey and Sons; 1981.

4. Danisworo. Sifat Fisik dan Kimia Batuan dan Mineral. Boor: Erlangga; 1994.

5. T HW. Petrology. New York, San Fransisco, Toronto London: McGraw-Hill Book Company; 1996

6. Mason B, Berry LG. Elements of Mineralogy. San Francisco: W.H.Freeman and Company; 1959.

7. Clarence Karr J. Infrared Spectroscopy of lunar and terrestrial minerals. New York: Academic Press; 1975. 